\title{
HYPOLIPIDAEMIC EFFECT OF COLD AQUEOUS EXTRACT MIXTURES OF GRAPE (VITIS VINIVERA) SEED, BASIL (OCIMUM BASILICUM) LEAVES AND MORINGA (MORINGA OLEIFERA) LEAVES IN RATS
}

\author{
A.E. EL-Beltagy and Warda A.Yousef \\ Food Science and technology Department, of Agriculture, Minufiya University, \\ Shebien EL-kom, Egypt.
}

Received: Sep. 24, 2019

Accepted: Oct. 2, 2019

\begin{abstract}
Different mixtures of (Moringa olifera leaves. Ocimum basilcum leaves and Grape seeds) as Mix A (Moringa leaves. basil leaves and Grape seeds), Mix. B (Moringa leaves and basil leaves), Mix. C Moringa olifera leaves and Grape seeds) and Mix D (basil leaves and Grape seeds) were analyzed for its total phenolic, total flavonoids contents, phenolic and flavonoids compounds then oral administration different mixtures with (200 and 100bwmg/k) to 60 sixty albino hypercholesterolemic rats aiming to improve their lipid profile. By the end of the experiment (28days) TC, TG, LDL, HDL, atherogenic indices (AC, CRR, Al) were analyzed. Mix A contained Total phenolic and Total flavonoid 1.23 and 0.07, Mix $B 1.06$ and 0.07, Mix $C 1.46$ and 0.09, Mix $D 1.16$ and 0.06 respectively. The highest total phenolic content and flavonoid in Mix C (1.46mg GAE g-1 DW) and flavonoid content ( $0.0068 \mathrm{mg}$ QE). Narinigin the major compound flavonoid of Mix A. Mix $B$ and Mix $C$ as 2165.36 ppm, 9201.27ppm and2978.04 ppm. While Hesperidin 910.17ppm major compound flavonoid of Mix $D$. The total cholesterol, triglyceride and LDL ratios were improved by $14.98 \%, 36.93 \%$ and $25.09 \%$ in groups were treated with Mix $A$ (200mg/kbw) compared with the positive control group. Significant high density lipoprotein (HDL) cholesterol and atherogenic indices (AC, CRR, $A l$ ), implying that hypochol-esterolemic effects of Mix. A $200 \mathrm{mg} / \mathrm{bw}$ of rats were partly attributed to the reduced absorption of lipid and cholesterol.
\end{abstract}

Key words: Moringa - Basil leaves - Grape seeds- Hypercholesterolemia - Total Phenolics - Total Flavonoids - Phenolics and Flavonoids Compounds

\section{INTRODUCTION}

Hypercholesterolemia is a common clinical metabolic and/or genetic disorder that promotes functional and structural vascular wall injury (Napoli and Lerman, 2001). The world health report estimates that worldwide about $8 \%$ of all disease burdens in developed countries is caused by raised cholesterol levels in excess of the theoretical minimum, $3.8 \mathrm{mmol} / \mathrm{L}$ (WHO, 2002). The underlying mechanisms for these deleterious effects involve a local inflammatory. Response and release of cytokines and growth factors (Napoli and Lerman, 2001). Total cholesterol levels above $200 \mathrm{mg} / \mathrm{dl}$ have repeatedly been correlated as an independent risk factor for development of peripheral vascular (PVD) and coronary artery disease (CAD)(Stapleton et al., 2010), thus, caused about $46 \%$ hypercholesterolemia treatment options that have become widely used, including pharmaceutical therapies which can decrease circulating cholesterol by preventing either its formation in the liver or its absorption in the intestine, also have pleiotropic effects witch can directly improve peripheral vascular outcomes (Stapleton et al., 2010). Moreover, drugs are not available over the counter and cannot be used for general health maintenance. Thus, increasing interests have drawn towards safe alternative 
products derived from natural bioresources (Thilakarathna and Rupasinghe, 2012). A lot work has been carried out by researches on various plants to evident their effectiveness in hypercholesterolemia (Harikumar et al., 2013). The aim of this study was to assess the effect Different mixtures of (grape seed, Moringa Oleifera Lam and Ocimum basilicum leaves) cold extract on Hypolipidaemic .

\section{MATERIALS AND METHODS Materials}

1. Plant samples:

Grape (Vitis vinivera) seeds Byproduct were obtained from jankliz Apo Elmtamer Elbhera Governorate; Basil (Ocimum basilicum) leaves were obtained from Faculty of Agriculture Tanta University in 2016. Moringa (Moringa oleifera) leaves obtained From EL-maghara north sine in July 2016.

\section{Reagents:}

Cholesterol powder cellulose, vitamins mixture and minerals mixture were obtained from EI Gomhorya Company, Cairo, Egypt. All analysis kits were purchased from Bio diagnostic Co., Giza, Egypt.

\section{Experimental Animals}

Sixty six adult male albino rats of Sprague Dawley strain weighing $(150 \pm 5$ g) were obtained from Research Institute of Ophthalmology, Animal House Department, Giza, Egypt.

\section{Methods}

1. Preparation of Moringa leaves, basil leaves and grape seeds powders

The leaves fresh of (Moringa, basil) and grape seeds were cleaned under running tap water to remove dirt and soil residues. Then it was dried at $40^{\circ} \mathrm{C}$ in an air draught oven and grinded to a fine powder and kept in dark glass bottle in deep freezer $\left(-16^{\circ} \mathrm{C}\right)$ for further analysis.

\section{Extraction of Moringa leaves, basil and grape seeds powders}

Powder (20g) was extracted with 400 $\mathrm{ml}$ (hot and cold) water solvent the flask in shaking incubator at $45^{\circ} \mathrm{C}$ for $10 \mathrm{~min}$ $2 \mathrm{~h}$ then left at room temperature $25^{\circ} \mathrm{C} \pm 2$ as for $\mathbf{2 4} \mathrm{hrs}$ the filtrate was separated using Whitman quantitative filter paper No.42, the residual of each tested plant material, another $400 \mathrm{ml}$ of the same solvent was added and left to another 24 hrs, and filtered. The extract was concentrated to dryness under reduced pressure and controlled temperature (45 $\left.50^{\circ} \mathrm{C}\right)$. The yield $(w / w)$ of the extract from fresh leaves was about 8-9\%. from each plant the extract was prepared in duplicate, and all analysis was carried out in triplicates.

\section{Chemical analysis}

\subsection{Chemical composition:}

The samples were analyzed for the extraction procedure used for the determination of total phenolic and total flavonoids was adapted from Chun et al. (2003) and Franke et al. (2004).

\subsection{Antioxidant activity:}

The DPPH assay described by Mandic et al. (2009) was utilized with some modifications. The stock reagent solution $\left(1 \times 10^{-3} \mathrm{~mol} \mathrm{~L}^{-1}\right)$ was prepared by dissolving $22 \mathrm{mg}$ of DPPH in $50 \mathrm{~mL}$ of methanol and stored at $-20 \circ \mathrm{C}$ until use. The working solution $\left(6 \times 10^{-5} \mathrm{~mol} \mathrm{~L}^{-1}\right)$ was prepared by mixing $6 \mathrm{~mL}$ of stock solution with $100 \mathrm{~mL}$ of methanol to obtain an absorbance value of $0.8 \pm 0.02$ at $515 \mathrm{~nm}$, as measured using a spectrophotometer. Solutions of different concentrations $(0.1 \mathrm{~mL}$ of each) were vortexed for $30 \mathrm{~s}$ with $3.9 \mathrm{~mL}$ of DPPH solution and left to react for $\mathbf{3 0} \mathrm{min}$, after 
which the absorbance at $515 \mathrm{~nm}$ was recorded. A control with no added extract was also analyzed. Scavenging activity was calculated as follows:

Radical scavenging activity $\%=$ $\left[\left(A^{\text {control }}-A^{\text {sample }}\right) / A^{\text {control }}\right] \times 100$

Where: $A$ is the absorbance at $515 \mathrm{~nm}$.

\subsection{Determination of Total Phenolic:}

Total phenolic content was determined by Kaur and Kapoor (2002) A $20 \mu \mathrm{L}$ aliquot of extract solution or processed jam (1 $\mathrm{g} 10 \mathrm{ml}$ methanol) solution was mixed with $1.16 \mathrm{~mL}$ of distilled water and $100 \mu \mathrm{L}$ of FolinCiocalteu's reagent followed by $300 \mu \mathrm{L}$ of $200 \mathrm{~g} \mathrm{~L}-1 \mathrm{Na} 2 \mathrm{CO} 3$ solution. The mixture was incubated in a shaking incubator at $40 \circ$ for $30 \mathrm{~min}$ and its absorbance at $\mathbf{7 6 0}$ $\mathrm{nm}$ was measured. Gallic acid was used as standard for the calibration curve. Total phenolic content expressed as Gallic acid equivalent (GAE) was calculated using the following linear equation based on the calibration curve: $A=0.98 C+9.925 \times 10-3(R 2=0.9996)$. where $A$ is the absorbance and $C$ is the concentration (mg GAEg-1 DW).

\subsection{Determination of total flavonoids}

Total flavonoid content was determined by the method of Chang et al. (2002) $0.5 \mathrm{~mL}$ aliquot of $20 \mathrm{~g} \mathrm{~L}-1 \mathrm{AICl} 3$ ethanolic solution was added to $0.5 \mathrm{~mL}$ of extract solution. After $1 \mathrm{~h}$ at room temperature the absorbance at $420 \mathrm{~nm}$ was measured. A yellow color indicated the presence of flavonoids. Extract samples were evaluated at a final concentration of $0.1 \mathrm{mg} \mathrm{mL}-1$. Total flavonoid content expressed as quercetin equivalent (QE) was calculated using the following equation based on the calibration curve: $y=0.0255 x(R 2=$ 0.9812 ) where $x$ is the absorbance and $y$ is the concentration (mg QEg-1 DW).

\section{Biological investigations}

\subsection{Experimental animals}

The work was carried out at Research Institute of Ophthalmology, Animal House Department, Giza, Egypt. Sixty-six male albino rats $(150 \mathrm{~g} \pm 5)$ were fed a standard diet for 7 days as an adaptation period. The standard diet was formulated according to AIN-93 guidelines Reeves et al., (1993) as shown in Table, (1). Salt mixture and vitamins mixture were prepared according to Hegested (1941) and Campbell (1963) as shown in Table (II) and (III). The rats were housed individually in wire cages under the normal laboratory conditions. Every day the rats were observed for the external appearance, shape, color and distribution of hair and physical activity. The diets were introduced to rats in special food cups to avoid loss of food and contamination. Also water was provided to rats by glass tube projecting through wire cages from inverted bottles supported to one side of the cage. Food and water provided were checked daily.

\subsection{Experimental groups:}

Male albino rats were divided randomly into two main groups, the first, negative control group (normal) $(n=6)$, fed on basal diet and the second group (hypercholesterolemic) $(n=60)$, was fed on diet containing cholesterol (1.5\%) and bile salts $(0.25 \%)$ for 21 consecutive days to achieve hypercholesterolemia. Then, the hypercholesterolemic group $(n=60)$ was divided into ten groups, 6 rats each. First group (positive control group) was fed on basal diet, the second was treted with drug simvaststin $3 \mathrm{mg} / \mathrm{kg}$. third and fourth groups were oral administration Mix A with (100 and $200 \mathrm{mg} / \mathrm{k} . \mathrm{bw})$ respectively, the fifth, sixth were oral administration Mix $S$ with (100 and 200 $\mathrm{mg} / \mathrm{k.bw}$ ) respectively, seventh, eighth were oral administration Mix C with (100 and $200 \mathrm{mg} / \mathrm{k} . \mathrm{bw}$ ) respectively. And the 
ninth, tenth were oral administration Mix C with (100 and 200 mg/k.bw) respectively.

\subsection{Blood collection:}

At the end of experimental period (30 days), rats were anesthetized with diethyl ether after fasting for $12 \mathrm{~h}$ and blood samples were collected by using the retro-orbital method by means of a micro capillary glass tubes. Blood was collected into a dry clean centrifugal tube and left to clot in a water bath $\left(-25^{\circ} \mathrm{C}\right)$ at room temperature for $0.5 \mathrm{~h}$. The blood was centrifuged for $10 \mathrm{~min}$ at $3000 \mathrm{rpm}$ to separate the serum. Serum was kept in clear quit fit plastic tubes and stored at $20^{\circ} \mathrm{C}$ until analysis.

\subsection{Biochemical assays}

The serum triglycerides (TG), high density lipoprotein (HDL) and total cholesterol (TC) were determined according to the methods described by Fossati and Prencipe, (1982); Demacker et al., (1980) and Covaci et al., (2006). The determination of low density lipoprotein cholesterol (LDLC) and very low density lipoprotein cholesterol (VLDLc) were carried out according to the method of Lee Castellii, (1977) as follows: VLDL= TG/5. LDL = Total cholesterol (HDL+VLDL).

Atherogenic indices [(cardiac risk ratio (CRR), atherogenic coefficient (AC) and atherogenic index (AI)] were determined according to (KikuchiHayakawa et al., 1998; Dobia's'ova' and Frohlich, 2001).

\subsection{Statistical analysis:}

All experiments were performed in five replicates. The data were recorded as means \pm standard deviations and analyzed with SPSS (version 12.0 for Windows, SPSS Inc., 223 South Wacker Drive, Chicago, USA). Differences were considered significant at $P<0.05$ (Keppel, 1991).

\section{RESULTS AND DISCUSSION}

1. Total phenolic and total flavonoids of cold water extract of different mixtures of moringa leaves, basil leaves and grape seeds

Table 1 showed The Effect of cold water extract on total phenolic and flavonoid of different mixture of Moringa leaves, basil leaves and Grape seeds. Total phenolic and flavonoid in Mixture of Moringa leaves, basil leaves and Grape seeds (Mix A), mixture of Moringa leaves and basil leaves (Mix B), mixture of Moringa leaves and Grape (Mix C) and mixture of basil leaves and Grape seeds showed are no different significantly at ( $P \leq 0.05)$. While the lowest Total phenolic and flavonoid in Mix $D$ mixture of basil leaves and Grape seeds.

Table 2 showed the effect of cold water extract on antioxidant of different mixture of Moringa leaves, basil leaves and Grape seeds. The highest Antioxidant were (Mix A) mixture of Moringa leaves, basil leaves and grape seeds followed by (Mix C) mixture of Moringa leaves and Grape seeds and (Mix B) mixture of Moringa leaves and basil leaves. While the lowest antioxidant Mix D mixture of basil leaves and Grape seeds.

These values in the same range as the values obtained by castillo-lópez et al. (2017) who stated that Moringa leaves contained DPPH was 86.82 and $87.92 \%$, respectively. Meanwhile, basil leaves. Katsube et al. (2004) who reported that basil leaves ranged from $58.43 \%-92.37 \%$ DPPH, respectively. On the other hand Grape seeds reported by Sonja et al. (2009) who reported that grape seeds Italian and Župljanka $79 \%$ and $95 \%$ mg dry seeds sample/mg DPPH radical. These results agree with our results. 
Table (1): Effect of aqueous extract on total phenolic, flavonoid on mixes of moringa leaves, basil leaves and grape seeds.

\begin{tabular}{|c|c|c|c|c|}
\hline $\begin{array}{c}\text { Prompter } \\
\text { Groups }\end{array}$ & $\begin{array}{c}\text { Mix A } \\
\text { Mean } \pm \text { SD }\end{array}$ & $\begin{array}{c}\text { Mix B } \\
\text { Mean } \pm \text { SD }\end{array}$ & $\begin{array}{c}\text { Mix C } \\
\text { Mean } \pm \text { SD }\end{array}$ & $\begin{array}{c}\text { Mix D } \\
\text { Mean } \pm \text { SD }\end{array}$ \\
\hline Total phenolic & $0.5674 \pm 0.12$ & $0.6728 \pm 0.2$ & $0.5128 \pm 0.16$ & $0.2044 \pm 0.008$ \\
\hline Total flavonoid & $0.0492 \pm 0.008$ & $0.0603 \pm 0.018$ & $0.0492 \pm 0.008$ & $0.0137 \pm 0.003$ \\
\hline
\end{tabular}

Mix A: (Moringa, basil and grape seeds) extracts (1:1: 1), Mix B (Moringa and basil) extracts (1: 1), Mix C (Moringa and grape seeds) extracts (1:1), Mix D (basil and grape seeds)extracts (1:1).

Table (2): Antioxidant activity of aqueous (cold) extracts of moringa leaves, basil leaves and grape seeds.

\begin{tabular}{|l|c|}
\hline Plants & DPPH (PPM) \\
\hline Mix A & $80.00 \pm 5.4$ \\
\hline Mix B & $78.00 \pm 7.07$ \\
\hline Mix C & $79.17 \pm 5.43$ \\
\hline Mix D & $77.17 \pm 1.64$ \\
\hline
\end{tabular}

The with different letters are significantly different $(p \leq 0.05)$.

Mix A: (Moringa, basil and grape seeds) extracts (1:1: 1), Mix B (Moringa and basil) extracts(1: 1), Mix C (Moringa and grape seeds) extracts (1:1), Mix D (basil and grape seeds)extracts (1:1).

\section{Identification of phenolic} compound of mixtures moringa leaves basil and grape seeds (Mix A, Mix B, Mix C and Mix D) cold extract by HPLC

Total Phenolic compounds Mixture of Moringa leaves, basil leaves and grape seeds (Mix A) cold water extract. (Mix A) contained Phenolic compounds, a higher amount of catechein was 206.44 ppm, Moringa leaves contain amount of catechein was 571.15 ppm, Grape seeds contain amount of catechein was $19.84 \mathrm{ppm}$ and basil leaves contain amount of catechein was $97.52 \mathrm{ppm}$. catechein is phenolic acid identified in water extracts of Moringa leaves, basil leaves and Grape seeds it was found to be contributed hyperlipidemia activity of plants. Our result agree with reported by Ngamukote et al. (2011) who showed that gallic acid and catechin major polyphenolic compounds have cholesterol-lowering activity by inhibiting pancreatic cholesterol esterase in Grape seeds extract. The concentration of phenolic compounds in cold water extract of Moringa leaves and basil leaves (Mix B) were determined (Table 3). There is a great variation in concentration of components which are identified cold water extract of (Mix B) contained 16 fractions of phenolic compounds. The highest amount of Phenolic compounds as catechein, pyrogallol and iso- ferullic as value $420.09 \mathrm{ppm}, 223.96 \mathrm{ppm}$, and $182.52 \mathrm{ppm}$. Identified in water extracts of Moringa leaves, basil leaves it was found to be contributed hyperlipidemia activity of plants. Our result agree with reported by Gajera et al. (2017) and (2018) who reported that's phenolic - gallic, catechin, and ferulic acids were a highly positively 
correlated with hyperlipidemia and free radical scavenging activity. In the same table (Mix C) contained the major phenolic compounds as catechein and Salicylic value as $158.79 p p m$ and 168.84 ppm. while the lowest amounts as caffic $2.69 \mathrm{ppm}$ and comarin $4.43 \mathrm{ppm}$. (Mix D) Cinnamic 186.54ppm and catechein 57.97 a major Phenolic compound of (Mix D) ppm. Our result agree with that reported by Gengaihi et al. (2014) who reported that catechin $20.4 \mathrm{ppm}$ was the major phenolic compounds have chloesrol lowering activity. While the lowest amounts of Phenolic compounds 0.83ppm Alpha coumaric and Amino value $2.61 \mathrm{ppm}$.

Table (3): Phenolic compound of mixture of Moringa leaves, basil leaves and grape seeds cold water extracts on HPLC.

\begin{tabular}{|c|c|c|c|c|}
\hline \multirow{2}{*}{ Phenolic compounds } & \multicolumn{4}{|c|}{ Phenolic compounds (ppm) } \\
\hline & Mix A & Mix B & Mix C & Mix D \\
\hline Gallic & 14.60 & 28.95 & 18.25 & 8.12 \\
\hline Pyrogallol & 81.92 & 223.96 & 50.83 & 31.46 \\
\hline 4-Aminobenzoic & 10.18 & 27.38 & 8.94 & 2.61 \\
\hline Protocatchuic & 29.74 & 76.28 & 27.53 & 17.58 \\
\hline Catechein & 206.44 & 420.09 & 158.79 & 57.97 \\
\hline Chlorogenic & - & 54.74 & 39.35 & 11.68 \\
\hline Catechol & 25.48 & 62.92 & 18.07 & 19.05 \\
\hline Caffeine & 53.45 & 80.58 & 31.62 & 36.50 \\
\hline P-OH-benzoic & 48.45 & 102.63 & 34.87 & 19.58 \\
\hline Caffeic & 18.27 & 45.39 & 2.69 & 3.03 \\
\hline Vanillin & 7.43 & 38.42 & 5.79 & 8.98 \\
\hline P-coumaric & 7.95 & 21.02 & 4.56 & 7.01 \\
\hline Ferulic & 7.33 & 44.08 & 12.25 & 5.26 \\
\hline Iso -Ferulic & 66.86 & 182.52 & 66.01 & 1.59 \\
\hline Alpha- coumaric & 6.42 & 24.04 & 6.86 & 0.85 \\
\hline Benzoic & 65.57 & 167.75 & 37.78 & 36.11 \\
\hline Salycillic & 196.64 & 146.71 & 168.84 & 20.71 \\
\hline 3,4,5 -methoxy-cinnamic & 12.01 & 19.89 & 5.49 & 5.11 \\
\hline Coumarin & 14.40 & 19.38 & 4.43 & 13.76 \\
\hline Cinnamic & 0.58 & 147.53 & 44.64 & 186.54 \\
\hline
\end{tabular}


3. Identification of flavonoid compounds in different mixtures (Mix A, Mix B, Mix C and Mix D) cold extract by HPLC.

Identification of Mix A flavonoid compounds by HPLC. Table (4) shows that (Mix A) contained a higher amount of Narinigin, Rutin and luteolin value as 2165.36ppm, $1941.08 \mathrm{ppm}$ and 206.42ppm respectively. Our result agrees with reported by Ding et al. (2012) who reported that Hesperidin reversed the hyperglycemia and hyperlipidemia by down regulating free radical generation. Priscillaet al. (2015) who showed that Naringenin inhibited the intestinal $\alpha$ glycosidase activity thereby decreasing lipid profile changes, improved antioxidant status and hepatic function markers. Hao et al. (2012) reported that Rutin was demonstrated to have protective effect against dyslipidemia induced nephropathy, neuropathy, liver damage. Whilemean the Mix B contained a higher amount Narinigenin, Rutin and quercetrin $9201.27 \mathrm{ppm}, 5470.07 \mathrm{ppm}$ and $466.62 \mathrm{ppm}$ respectively of flavonoid compounds. In concert the lowest amounts of flavonoids value as Hesprtin and Apegnin 16.60 and $23.33 \mathrm{ppm}$. Our result agree with that reported by Panda and Kar (2007) who reported that Apigenin was efficient in overcoming hyperlipidemia and reduced antioxidants like SOD, CAT, GSH in cholesterols induced hyperlipidemia rats. It also efficacy in glucose lowering. Hesperidin reversed the hyperglycemia and hyperlipidemia by down regulating free radical generation Ding et al. (2012). Whilmeam (Mix C) contained the highest amounts of flavonoid compounds as Narinigenin $2978.04 \mathrm{ppm}$ and Hesbirdin 1959.84 ppm. Ding et al. (2012) who showed that Hesperidin reversed the hyperglycemia and hyperlipidemia by down regulating free radical generation.
Priscilla et al. (2015) Reported that Naringenin inhibited the intestinal $\alpha-$ glycosidase activity thereby decreasing the levels of lipid profile changes, improved antioxidant status and hepatic function markers.

Mix D contained a higher amount of as Hesbirdin $910.17 \mathrm{ppm}$ and luteolin 29.42ppm, Our results agree with reported by Grassi et al. (2008) who examined that hyperlipidemia herbs and their compounds were proven to significantly hyperlipidemia. Flavonoids form the biggest family of polyphenolic herbal compounds which are being demonstrated to possess antihyperglycaemic and anti-hyperlipidemic.

\section{Effect of feeding on different mixtures of Moringa leaves, basil leaves and grape seeds cold water extract (100 and $200 \mathrm{mg} / \mathrm{kg}$ ) on triglycerides and total cholesterol in} hyperlipidemic rats

The results in Table (5) showed the level of triglycerides and cholesterol in control and experimental rats as well as the reduction rate occur via treating with mixture of moringa leaves, basil leaves and grape seeds cold water extracts. The results showed significant $(p \leq 0.05)$ increase of lipids profile (TC and TG) level in all groups of chemically induced hypercholesterolemia compared with normal control. All treated showed groups an improve $(P \leq 0.05)$ of lipids profile level (TC and TG) in rats by oral administration of Mix A, MixB, Mix C and Mix D by 100 and $200 \mathrm{mg} / \mathrm{kg}$ when compared with the control positive group. The groups treated with drug (simvastatin) showed the highest improve $(P \leq 0.05)$ in level of triglycerides and cholesterol compared with all treated groups. A higher improving ( $P \leq 0.05)$ level of triglycerides group was treated Mix A with $200 \mathrm{mg} / \mathrm{kg}$. (63.7). While cholesterol 
level showed improving in all groups compared the control positive. In contrast, the groups treated with drug (simvastatin) showed a higher improve $(P \leq 0.05)$ compared with all treated groups. As well as group was treated Mix A with $200 \mathrm{mg} / \mathrm{kg}$ (106.7) had no a significant ( $p \leq 0.05)$ change on cholesterol level compared with the group treated with drug (105.6) followed by group treated with mixture of basil leaves and grape seeds by $200 \mathrm{mg} / \mathrm{kg}$ (109.67). The result are agreement with that reported by Ganjali et al (2012) who reported that the methanolic extract of grape seeds effective in the treatment cholesterol, triglyceride, This effect may be due to the presence of flavonoids and antioxidant properties of grape seeds. Reddy et al. (2017) who reported that the polyphenol extract of Moringa leaves has a significant cholesterol lowering effective. Ding et al. (2012) showed that Hesperidin reversed the hyperglycemia and hyperlipidemia by down regulating free radical generation.

Table (4): Flavonoid compound of mixtures of Moringa leaves, basil leaves and grape seeds cold water extracts on HPLC.

\begin{tabular}{|l|c|c|c|c|}
\hline \multirow{2}{*}{ Flavonoid } & \multicolumn{4}{c|}{ Flavonoid (ppm ) } \\
\cline { 2 - 5 } & Mix A & Mix B & Mix C & MixD \\
\hline Apig-6-arbinose8-glactose & 25.95 & 73.23 & 3.84 & 10.95 \\
\hline Aig-6-rhanmnose 8-glucose & 39.35 & 52.19 & 35.57 & 20.50 \\
\hline Luteolin & 206.42 & 711.44 & 206.95 & 29.42 \\
\hline Narinigin & 2165.36 & 9201.27 & 2978.04 & 49.99 \\
\hline Rutin & 1941.08 & 5470.07 & 495.76 & 42.91 \\
\hline Hesbirdin & 1138.90 & 3212.63 & 1959.84 & 910.17 \\
\hline Apigenin7-O-neohespiroside & 11.19 & 27.91 & 7.19 & 3.66 \\
\hline Quercetrin & 133.74 & 466.62 & 162.56 & 13.74 \\
\hline Quercetin & 10.64 & 35.39 & 8.62 & 6.96 \\
\hline Kamp.3.(2-p-comaroyl)glucose & 91.69 & 163.19 & 74.28 & 33.59 \\
\hline Acacetin neo-rutiiinoside & 17.65 & 117.94 & 14.98 & 17.45 \\
\hline Naringenin & 2.65 & 1.15 & 0.71 & 0.57 \\
\hline Hespirtin & 10.69 & 16.60 & 4.54 & 2.79 \\
\hline Kampferol & 14.79 & -- & 17.24 & 15.19 \\
\hline Apegnin & 12.33 & 23.23 & 7.18 & 11.57 \\
\hline
\end{tabular}


Table (5): Effect of cold water extracts different mixtures of Moringa leaves, basil leaves and grape seeds cold water extract $(100$ and $200 \mathrm{mg} / \mathrm{kg})$ on triglycerides and total cholesterol of hyperlipidemic rats

\begin{tabular}{|l|c|c|}
\hline \multicolumn{1}{c}{ Groups } & Triglycerides & Cholesterol \\
\cline { 2 - 3 } & Mean \pm SD & Mean \pm SD \\
\hline Control Negative & $43.7 \pm 2.08^{\mathrm{e}}$ & $102.3 \pm 2.52^{\mathrm{c}}$ \\
\hline Control Positive & $101 \pm 2.65^{\mathrm{a}}$ & $125.50 \pm 3.28^{\mathrm{a}}$ \\
\hline G3 & $44.9 \pm 2.85^{\mathrm{e}}$ & $105.6 \pm 3.27^{\mathrm{c}}$ \\
\hline Mix A 100mg/bw & $69.3 \pm 3.21^{\mathrm{c}, \mathrm{d}}$ & $110.3 \pm .2 .52^{\mathrm{b}, \mathrm{c}}$ \\
\hline Mix A 200mg/bw & $63.7 \pm 1.53^{\mathrm{d}}$ & $106.7 \pm 3.50^{\mathrm{c}}$ \\
\hline Mix B 200mg/bw & $84.2 \pm 1.04^{\mathrm{b}}$ & $117.3 \pm 2.05^{\mathrm{b}}$ \\
\hline Mix B 100mg/bw & $81.3 \pm 2.52^{\mathrm{b}}$ & $115.3 \pm 2.08^{\mathrm{b}, \mathrm{c}}$ \\
\hline Mix C 200mg/bw & $76.3 \pm 1.52^{\mathrm{b}, \mathrm{c}}$ & $110.7 \pm 2.52^{\mathrm{b}}$ \\
\hline Mix C 200mg/bw & $73.7 \pm 2.08^{\mathrm{c}}$ & $113.3 \pm 3.6^{\mathrm{b}, \mathrm{c}}$ \\
\hline Mix D 100mg/bw & $73.7 . \pm 2.08^{\mathrm{c}}$ & $109.9 \pm 2.52^{\mathrm{b}, \mathrm{c}}$ \\
\hline Mix D 200mg/bw & $71.0 \pm 2^{\mathrm{c}}$ & $109.67 \pm 3.06^{\mathrm{b}, \mathrm{c}}$ \\
\hline
\end{tabular}

Data are presented as (Mean \pm SEM), SEM = Standard error of mean.

Mean values with different superscript letters in the same column are significantly different at (PS0.05).

5. Effect of feeding on different mixtures of Moringa leaves, basil leaves and grape seeds cold water extract (100 and $200 \mathrm{mg} / \mathrm{kg}$ ) on lipoproteins of hyperlipidemic rats.

The results in Table (6) showed the activity of serum lipoprotein level of HDL and LDL activities in control and experimental rats as well as the reduction rate occur via treating with mix of moringa leaves, basil and grape seeds cold water extract on lipoproteins of rats. The results showed significant $(p \leq 0.05)$ decrease of the level of lipoproteins HDL and increase of LDL in all groups of chemicallyinduced hypercholesterolemia compared with normal control. The result showed an improve $(P \leq 0.05)$ in serum lipoprotein level of HDL and LDL by oral administration of Mix A, Mix B, Mix C and $M x D)$ by 100 and $200 \mathrm{mg} / \mathrm{kg}$ when compared with the control positive group. In contrast, the groups treated with drug (simvastatin) showed a higher improve $(P \leq 0.05)$ in $H D L$ and $L D L$ level compared with all treated group. The highest improve $(P \leq 0.05)$ of $\mathrm{HDL}$ was detected in the group treated with Mix A extracts by $100 \mathrm{mg}$ and $200 \mathrm{mg} / \mathrm{kg} 43.07$ 
and 44.40 as well as the groups treated with drug (simvastatin) 45.67 had no a significant $(P \leq 0.05)$ changes compared with all treated groups. Meanwhile, The LDL level was observed in all groups treated with Mix A, Mix B, Mix C and Mix $D$ by $100 \mathrm{mg}$ and $200 \mathrm{mg} / \mathrm{kg}$ had no a significant $(P \leq 0.05)$ changes compared with group positive. The best result of LDL groups treated with drug (simvastatin). Our result agree with that reported by Souravh et al. (2014) who reported that, moringa leaves effective in the treatment HDL, LDL of hypercholesterolemia. This effective may be due to the presence of total phenolic and flavonoids of moringa leaves. Ganjali et al. (2012) showed that the methanolic extract of grape seeds effective in the treatment HDL, VLDL of hypercholesterolemia. This effect may be due to the presence of flavonoids and antioxidant properties of grape seeds. Hao et al. (2012) reported that Rutin was demonstrated to have protective effect against hyperglycemia and dyslipidemia induced nephropathy, neuropathy, liver damage. Priscilla et al. (2015) reported that Naringenin inhibited the intestinal $\alpha-$ glycosidase activity thereby decreasing the levels lipid profile, improved antioxidant status and hepatic function markers.

Table (6): Effect of cold water extracts different mixtures of moringa leaves, basil leaves and grape seeds 100 and $200 \mathrm{mg} / \mathrm{kg}$ on lipoproteins in hyperlipidemic rats.

\begin{tabular}{|c|c|c|c|}
\hline Parameters & HDL & LDL & VLDL \\
\hline & Mean \pm SD & Mean \pm SD & Mean \pm SD \\
\hline Control Negative & $46.67 \pm 1.53^{a}$ & $47.3 \pm 2.08^{d}$ & $8.73 \pm 0.41$ \\
\hline Control Positive & $31 \pm 0.50^{d}$ & $71.9 \pm 1.79^{a}$ & $30.26 \pm 17.95$ \\
\hline G3 & $45.33 \pm 2.08^{a}$ & $49.9 \pm 2.80^{d}$ & $8.98 \pm 0.73$ \\
\hline Mix A $100 \mathrm{mg} / \mathrm{bw}$ & $43.07 \pm 1.26^{a . b}$ & $58.3 \pm 3.01^{b}$ & $12.73 \pm 0.30$ \\
\hline MixA200mg/bw & $44.40 \pm 1.44^{a}$ & $53.9 \pm 2^{c}$ & $9.86 \pm 0.64$ \\
\hline Mix B 200mg/b & $34.17 \pm 1.72^{c}$ & $63.3 \pm 1.2^{b}$ & $16.83 \pm 0.20$ \\
\hline MixB $100 \mathrm{mg} / \mathrm{bw}$ & $36.07 \pm 2.10 c$ & $61.3 \pm 1.53^{b}$ & $16.26 \pm 0.50$ \\
\hline MixC 200mg/bw & $37.93 \pm 1.06^{b . c}$ & $60.5 \pm 2.52^{b}$ & $45.8 \pm 0.30$ \\
\hline MixC $200 \mathrm{mg} / \mathrm{bw}$ & $39.20 \pm 1.06^{b}$ & $58.0 \pm 1.35^{b}$ & $8.8 \pm 0.41$ \\
\hline Mix D 100mg/bw & $40.43 \pm 1.00^{, b}$ & $59.3 \pm 2.52^{b}$ & $14.73 \pm .41$ \\
\hline Mix D 200mg/bw & $42.00 \pm 1.69^{a, b}$ & $56.2 \pm 1.37^{\mathrm{b}, \mathrm{e}}$ & $14.2 \pm 0.4$ \\
\hline
\end{tabular}

Data are presented as (Mean \pm SEM), SEM = Standard deviation of mean.

Mean values with different superscript letters in the same column are significantly different at $(P \leq 0.05)$. 
6. Effect of feeding on different mixtures of Moringa leaves, basil leaves and grape seeds cold water extract $(100$ and $200 \mathrm{mg} / \mathrm{kg}$ ) on Al. CRR. CRI. AF and $A C$ of normal and hyperlipidemic rats.

Data in Table (7) showed the effect of mixs of moringa, basil and grape seeds on AI. CRR. CRI .AF and AC of normal control and hypercholesterolemia rats. The results in Table (7) showed the level of (Al.CRR.CRI.AF and AC) all groups were improving compared the control positive all groups reduced (AI.CRR.CRI.AF and AC) level compared positive control. In contrast, the groups treated with drug (simvastatin) showed a higher improved compared with all treated groups. The best result in group was treated with Mix A and Mix D $100 \mathrm{mg}$ and $200 \mathrm{mg} / \mathrm{kg}$ of body weight. The level of atherogenic coefficient (IA) was improved when the hypercholesterolemic rats that administrated with Mix $A$ and Mix D (100mg and 200mg / kg bw) and Mix C with $200 \mathrm{mg} / \mathrm{k}$ bw compared to positive control group. The best hypercholesterolemic group in cardiac risk ratio (CRR and $A C$ ) was that administrated with Mix $A$ and Mix D (100mg and $200 \mathrm{mg} / \mathrm{kg}$ of bw) and Mix C with $200 \mathrm{mg} / \mathrm{k}$ bw while the lowest improvement was in Mix B100mg and $200 \mathrm{mg} / \mathrm{kg}$ of bw) and Mix C with 100mg. On Onther hand The level of atherogenic coefficient (CRI and FA) was improved when the hypercholesterolemic rats that administrated with Mix A and Mix D (200mg / kg bw). Atherogenic indices are powerful indicators of the risk of heart disease the higher the value, the higher the risk of developing CVD and vice versa (Usoro et al., 2006 and Krishna, 2013).
7. Effect of feeding on different mixtures of Moringa leaves, basil leaves and grape seeds cold water extract (100 and $200 \mathrm{mg} / \mathrm{kg}$ ) on antioxidant activity of normal and hyperlipidemic rats.

Table (8) revealed the effects of feeding mixture of moringa leaves, basil leaves and grape seeds extracts on (SOD - MDA) in hyperlipidemia rats. The results showed the activity of liver tissue oxidative marker (MDA, and SOD activities) in control and experimental rats as well as the reduction rate occur via treating with mix of moringa leaves, basil leaves and grape seeds extracts. The results showed significant $(p \leq 0.05)$ increase of oxidative marker MDA, and decrease of SOD in all groups of chemically induced hypercholesterolemia compared with normal control. All groups rats treated showed improving ( $\mathrm{P} \leq 0.05)$ of MDA, and SOD activities when compared control positive group by oral administration of Mix A, MixB, MixC and MixD with 100 and $200 \mathrm{mg} / \mathrm{kg}$ when compared with the control positive group. In contrast, the groups treated with drug (simvastatin $3 \mathrm{mg} / \mathrm{kg}$ ) showed a higher improve $(P \leq 0.05)$ compared with all treated groups. The groups treated with Mix A cold extracts by $200 \mathrm{mg} / \mathrm{kg}$ as well as the groups treated with drug (simvastatin) had no a significant $(P \leq 0.05)$ changes of level MDA. While the best result of SOD level groups treated with Mix A flowed to Mix $C$ and Mix D by 100 and $200 \mathrm{mg} / \mathrm{kg}$ showed a higher improving ( $P \leq 0.05)$ when compared with the control positive group. In contrast, the groups treated with drug (simvastatin) showed a higher improve $(P \leq 0.05)$ compared with all treated groups. This result agree with that reported by Reddy et al. (2017) who 
reported that Treatment with Moringa leaves extract reduce the level of MDA and increase of SOD. Sakr and AlAmoudi (2012) reported that basil leaves cold water extract Reduction in the level of MDA (lipid peroxidation marker) and increase in the activities of SOD. The present investigation suggested that moringa leaves, basil leaves and grape seeds cold extracts had a potential role in therapeutic action via inhibiting oxidative stress due to presence of phenolic compounds and its anti-oxidant nature that $s$ result agree with that reported by Jaiswal et al. (2013) who reported that moringa leaves extracts increasing SOD, CAT, GSH and decreased level lipids in hyperlipidemia rats.

Table (7): Effect of cold water extracts different mixtures of moringa leaves, basil leaves and grape seeds extracts $200 \mathrm{mg} / \mathrm{kg}$ on lipids profile of hyperlipidemic rats

\begin{tabular}{|c|c|c|c|c|c|}
\hline Par & Al & CRR & CRI & FA & $A C$ \\
\hline Groups & Mean \pm SD & Mean \pm SD & Mean \pm SD & Mean \pm SD & Mean \pm SD \\
\hline Control Negative & $0.93 \pm 0.25^{f}$ & $2.19 \pm 0.55^{e}$ & $1.02 \pm 0.75^{f}$ & $0.46 \pm 0.01^{a}$ & $1.19 \pm 0.55^{\mathrm{e}}$ \\
\hline Control Positive & $3.24 \pm 0.13^{a}$ & $4.03 \pm 0.17^{a}$ & $2.31 \pm 0.10^{a}$ & $0.25 \pm 0.01^{\mathrm{e}}$ & $3.03 \pm 017^{a}$ \\
\hline G3 & $0.99 \pm 0.10^{f}$ & $2.34 \pm 0.13^{e}$ & $1.10 \pm 0.30^{e f}$ & $0.43 \pm 0.26^{a b}$ & $1.34 \pm 0.17^{e}$ \\
\hline Mix A $100 \mathrm{mg} / \mathrm{bw}$ & $1.62 \pm 016^{e}$ & $2.5 \pm 0.10^{e}$ & $1.36 \pm 0.65^{d}$ & $0.39 \pm 0.01^{b}$ & $1.56 \pm 0.100^{\mathrm{e}}$ \\
\hline MixA200mg/bw & $1.43 \pm 0.75^{d}$ & $2.40 \pm 0.05^{\mathrm{de}}$ & $1.22 \pm 0.72^{\text {de }}$ & $0.42 \pm 0.00^{b}$ & $1.40 \pm 0.005^{\mathrm{de}}$ \\
\hline Mix B $100 \mathrm{mg} / \mathrm{bw}$ & $2.46 \pm 0.75 b$ & $3.44 \pm 0.17^{b}$ & $1.85 \pm 0.10^{b}$ & $0.29 \pm 0.02^{\mathrm{e}}$ & $2.44 \pm 0.13^{b}$ \\
\hline MixB 200mg/bw & $2.26 \pm 0.20^{b}$ & $3.12 \pm 0.17^{b}$ & $1.70 \pm 0.07^{b}$ & $0.32 \pm 0.15^{d}$ & $2.12 \pm 0.17^{b}$ \\
\hline Mixc $100 \mathrm{mg} / \mathrm{bw}$ & $2.01 \pm 0.85^{c}$ & $3.04 \pm 0.8^{c}$ & $1.60 \pm 0.61^{c}$ & $0.33 \pm 0.01^{d}$ & $2.04 \pm 0.83^{c}$ \\
\hline MixC 200mg/bw & $1.87 \pm 0.86^{c}$ & $2.83 \pm 0.15^{c}$ & $1.48 \pm 0.05^{c}$ & $0.35 \pm 0.02^{c}$ & $1.83 \pm 0.15^{c}$ \\
\hline Mix D 100mg/bw & $1.82 \pm 0.10 \mathrm{~d}$ & $2.81 \pm 0.16^{d}$ & $1.47 \pm 0.04^{\mathrm{cd}}$ & $0.35 \pm 0.02^{c}$ & $1.81 \pm 0.16^{\mathrm{cd}}$ \\
\hline Mix D 200mg/bw & $1.67 \pm 0.68^{c}$ & $2.61 \pm 0.08^{\mathrm{cd}}$ & $1.34 \pm 0.03^{d}$ & $3.80 \pm 0.01^{c}$ & $1.61 \pm 0.08^{\mathrm{cd}}$ \\
\hline
\end{tabular}

Means in the same row with different letters are significantly different $(p<0.05)$. G3: rats treated with simvastatin3mg/kg. Mix A (Moringa leaves, basil leaves and grape seeds) extracts (1:1: 1 ), Mix B ((Moringa leaves and basil leaves ) extracts(1: 1), Mix C (Moringa leaves and grape seeds) extracts (1:1), Mix D (basil leaves and grape seeds)extracts(1:1) Data presented are in means \pm standard deviations for five replicates in each group. Values in the same row not sharing a common superscript letter differ significantly at $P<0.05$. * CRR $=$ Cardiac risk ratio, $(A C)=$ Atherogenic coefficient, AF =Atherogenic Fraction, Al= Atherogenic Index, CRI = Atherogenic Indix 
Table (8): Effect of cold water extracts different mixtures of moringa leaves, basil leaves and grape seeds extracts on (SOD - MDA) in hyperlipidemic rats.

\begin{tabular}{|c|c|c|}
\hline \multirow[t]{2}{*}{ Parameters } & MDA & SOD \\
\hline & Mean \pm SD & Mean \pm SD \\
\hline Control Negative & $35.67 \pm 1.53^{\mathrm{g}}$ & $0.80 \pm 0.05^{a}$ \\
\hline Control Positive & $2.46^{\mathrm{a}} \pm 81.80$ & $0.024 \pm 0.02^{f}$ \\
\hline G3 & $36.50 \pm 1.55^{9}$ & $0.01^{b} \pm 0 . .60$ \\
\hline Mix of $E(M+G) 100 \mathrm{mg} / \mathrm{bw}$ & $43.70 \pm 1.61^{f}$ & $0.52 \pm 0.03^{, c}$ \\
\hline Mix of $E(M+G) 100 \mathrm{mg} / \mathrm{bw}$ & $38.63 \pm 1.72^{\mathrm{g}}$ & $0.50 \pm 0.02^{c}$ \\
\hline Mix of $E(M+B) 100 \mathrm{mg} / \mathrm{bw}$ & $68.33 \pm 3.21^{b}$ & $0.32 \pm 0.02^{\mathrm{e}}$ \\
\hline Mix of $E(M+B) 100 \mathrm{mg} / \mathrm{bw}$ & $64.05 \pm 1.29, c$ & $0.34 \pm 0.01^{\mathrm{e}}$ \\
\hline Mix of $E(M+G) 100 \mathrm{mg} / \mathrm{bw}$ & $56.03 \pm 2.16, d$ & $0.48 \pm 0.01^{c}$ \\
\hline Mix of $E(M+G) 100 \mathrm{mg} / \mathrm{bw}$ & $51.47 \pm 1.50^{\mathrm{e}}$ & $0.51 \pm 0.05^{c}$ \\
\hline Mix of $E(B+G) 100 \mathrm{mg} / \mathrm{bw}$ & $46.50 \pm 1.54^{f}$ & $0.41 \pm 0.02^{c d}$ \\
\hline Mix of $E(B+G) 200 \mathrm{mg} / \mathrm{bw}$ & $44.60 \pm 1.62^{f}$ & $0.45 \pm 0.03^{c d}$ \\
\hline L SD & 3.359 & 0.054 \\
\hline
\end{tabular}

Data are presented as (Mean \pm SEM).

SEM = Standard Divenation of mean.

Mean values with different superscript letters in the same column are significantly different at $(\mathrm{P} \leq 0.05)$.

\section{CONCLUSION}

In conclusion, of mixtures of moringa, basil leaves and grape seeds were efficient in the protection against hypercholesterolemia by decreasing serum TC, TG, TI, and LDL-C and increasing HDL-C, and thus decreasing the atherogenic indices (AC, CRR, Al). Notably, the studied could be considered as potential sources of flavonoids, phenolic compounds and antioxidant activity which could be used in a wide variety of applications, mainly in the food and confectionary industries. The pharmaceutical, cosmetic and perfume industries are other possible outlets of these flavonoids, phenolic compounds and antioxidant activity.

\section{REFRENCES}

Adikwuru, C.C., I.N. Usoro and A.C. Nsonwu (2006)."Lipid Profile of Postmenopausal Women in Calabar, Nigeria".Pak. J. Nutr. 5:79-82.

Campbell, J.A. (1963). Methodology of Protein Evaluation. PAG Nutr. Document R. 101 Led. 37 June Meeting, New York, U.S.A.

Castelli, W. (1977). HDL cholesterol and other lipids in coronary heart disease. 
The cooperative lipoprotein phenotyping study. Circulation, 55: 767.

Casterelli, T. and Y. Levitar (1977). Atherogenic Index. Curr. Presc., P 39.

Castillo-Lopez, R.I., J. Leon-Felix, M.A. Angulo-Escalante, R. GutierrezDorado, M.D. Muy-Rangel and J.B. Heredia (2017). Nutritional and phenolic characterization of Moringa oleifera leaves grown in Sinaloa, Mexico. Pakistan. J. of Botany. 49: 161-168.

Chang, C., M. Yang, H. Wen and J. Chern (2002). Estimation of total flavonoid content in propolis by two complementary colorimetric methods. J. Food Drug Anal., 10(3):178-182.

Choi, H. S. (2005). Characteristic odor components of kumquat (Fortunella japonica Swingle) peel oil. Journal of Agricultural and Food Chemistry, 53, 1642-1647.

Chun, O.K., D.O. Kim, H.Y. Moon, H.G. Kang and C.Y. Lee (2003). Contribution ofindividual polyphenolics to total antioxidant capacity of plums. J. Agric. Food Chem. 51,7240-7245

Covaci, A., S. Voorspoels, C. Thomsen, B. van Bavel and H. Neels (2006). Evaluation of Total Lipids Using Enzymatic Methods for the Normalization of Persistent Organic Pollutant Levels in Serum. Science of The Total Environment, Volume 366, Issue 1, Pages 361-366.

Demacker, P. M., H.E. Von-janssen and A.M. Hifman (1980). Vants lear, A. and jansen, A.P. Measurment of high density lipoprotein cholesterol in serum. Comparison of six isolation methods combined with enzymatic cholesterol analysis. Clin. Chem. 26: 1780-1789.

Ding, X., S. Fan, Y. Lu, Y. Zhang, M. Gu, L. Zhang, G. Liu, L. Guo, D. Jiang, $X$. Lu, Y. Li, Z. Zhou and C. Huang (2012). Citrus ichangensis peel extract exhibits anti-metabolic disorder effects by the inhibition of PPARY and LXR signaling in high-fat diet-induced C57BL/6 mouse. Evidence-Based Complementary and Alternative Medicine. 1-10.

Ding, F., J.X. Diao and Y. Sun (2012). Bioevaluation of human serum albumin-hesperidin bioconjugate: insight into protein vector function and conformation. J. Agric. Food Chem., 60; 7218-7228.

Dobia'šova Milada' and Jiri Frohlich (2001). The plasma parameter log (TG/HDL-C) as aatherogenic index: correlation with lipoprote particle size and esterification rate in apoBlipoprotein- depleted plasma (FERHDL). Clinica Biochemistry, 34(7): $583-588$.

Fossati, P. and I. Prencipe (1982). Serum triglycrides determination colorimetrically with an enzyme that produce hydrogen peroxide. Clin.Chem. 28: 2077-2083.

Franke, A.A., L.J. Custer, C. Arakaki and S.P. Murphy (2004). Vitamin C and flavonoid levels of fruits and vegetables consumed in Hawaii. Journal of Food Composition and Analysis 17: 1-35.

Gajera, H.P., Z.A. Katakpara, S.V. Patel and B.A. Golakiya (2016). Antioxidant defense response induced by Trichoderma viride against Aspergillus niger Van Tieghem causing collar rot in groundnut (Arachis hypogaea L). Microbial Pathogenesis, 91(1): 26-34.

Gajera, H.P., N. Gevariya Shila, G. Hirpara Darshna, S.V. Patel and B.A. Golakiya (2017). Antidiabetic and antioxidant functionality associatead with phenolic constituents from fruit parts of indigenous black jamun (Syzygium cumini L.) landraces. J Food Sci Technol., 54(10): 3180-3191.

Gajera, H.P., N. Gevariya Shila, S.V. Patel and B.A. Golakiya (2018). Nutritional 
profile and molecular fingerprints of indigenous black jamun (Syzygium cumini L.) landraces. Journal of Food Science and Technology. 55(2): 730739.

Ganjali, Z., F. Javadian, J. Estakhr and A. Heidari (2012). The effect of hydroalcoholic extract of grape seed (Vitis vinifera) on sugar and lipids in serum of diabetic rats. $n$ AGRIS since.,4: 173175.

Gengaihi, S.E.I., F.M.A. Ella, M.H. Emad, E. Shalaby and H. Doha (2014). Antioxidant activity of phenolic compounds from different Grape wastes. J Food Process Technol., 5: 296.

Grassi, D., G. Desideri, S. Necozione, C. Lippi, R. Casale, G. Properzi, J.B. Blumberg and C. Ferri (2008). Blood pressure is reduced and insulin sensitivity increased in glucose intolerant, hypertensive subjects after 15 days of consuming high polyphenol dark chocolate. J Nutr., 138 (9):1671 - 1676.

Hao, H.H., Shao ZM, Tang DQ, Lu Q, Chen $X$, et al. (2012). Preventive effects of Rutin on the development of experimental diabetic nephropathy in rats. Life sci. 91(19-20): 959-967.

Harikumar, K., S. Abdul Althaf, B. Kishore kumar, M. Ramunaik and $\mathrm{CH}$. Suvarna A (2013). Review on Hyperlipidemic. International J. of Novel Trends inPharmaceuticalSciences 59:71.

Hegested, A. (1941). Salt mixture. J. Biol. Chem., 138:459.

Jaiswal, D., P. Rai, K.S. Mehta, S. Chatterji, S. Shukla, D.K. Rai, G. Sharma, B. Sharma, S. Khair and G. Watal (2013). Role of Moringa oleifera in regulation of diabetes-induced oxidative stress. Asian Pacific J. of Tropical Medicine. 426-432.

Jung, C. H., I. Cho, J. Ahn, T.I. Jeon and T.Y. Ha (2012). Quercetin reduces high-fat dietinduced fat accumulation in the liver by regulating lipid metabolism genes. Phytotherapy Research.

Katsube, T., H. Tabata, Y. Ohta, Y. Yamasaki, E. Anuurad, K. Shiwaku and Y. Yamane (2004): Screening for antioxidant activity in edible plant products: comparison of low-density lipoprotein oxidation assay, DPPH radical scavenging assay, and FolinCiocalteu assay. J Agric Food Chem., 52(8): 2391-6.

Kaur, C. and H.C. Kapoor (2002). Antioxidant activity and total phenolic content of some Asian vegetables. International Journal of Food Science \& Technology. 37(2): 153-161.

Kikuchi-Hayakawa, H., N. Onodera, S. Matsubara, E. Yasuda, Y. Shimakawa and F. Ishikawa (1998). Effects of soya milk and Bifidobacterium-fermented soya milk on plasmaand liver lipids, and faecal steroids in hamsters fed on a cholesterol-free or cholesterolenriched diet.British Journal of Nutrition, Volume 79, Issue 01, pp 97105.

Krishna Gopal Rao. (2013). Hypoglycemic activity of extracts from Elytraria acaulis L. Leaves in alloxan induced diabetic rats. 1(1):11-16.

Lee Jeong-Sun, Song-Hae Bok, Seon-Min Jeon, Hye-Jin Kim, Kyung-Min Do, Yong-Bok Park and Myung-Sook Choi (2010). Antihyperlipidemic effects of buckwheat leaf and flower in rats fed a high-fat diet. Food Chemistry, Pages 235-240.

Lee Jeong-Sun, Song-Hae Bok, Seon-Min Jeon, Hye-Jin Kim, Kyung-Min Do, Yong-Bok Park, and Myung-Sook Choi (2010). Antihyperlipidemic effects of buckwheat leaf and flower in rats fed a high-fat diet. Food Chemistry, Pages 235-240.

Mandić, A.I., S. M. Djilas, Č. Brunet, G.S. Ćetković and J. J. Vulić (2009). Antioxidant activity of white grape seed extracts on DPPH radicals. APTEFF, 40: 1-220. 
Murphy, S.P. (2004). Vitamin C and flavonoidlevels of fruits and vegetables consumed Hawaii. Journal of Food Composition and Analysis 17, 1-35.

Napoli, C. and L.O. Lerman (2001). Involvem of oxidation-sensitive mechanisms in the cardiovascular effects of hypercholesterolemia Mayo Clin Proc. 76 (6):619-31.

Ngamukote, S., K. Mäkynen, T. Thilawech and S. Adisakwattana (2011). Cholesterol-lowering activity of the major polyphenols in grape seed. Molecules., 16:5054-5061.

Panda, S. and A. Kar (2007). Apigenin (4',5,7-trihydroxyflavone) regulates hyperglycaemia, thyroid dysfunction and lipid peroxidation in alloxaninduced diabetic mice. J Pharm Pharmacol., 59(11): 1543-1548.

Priscilla, D.H., M. Jayakumar and K. Thirumurugan (2015). Flavanone naringenin: An effective antihyperglycemic and antihyperlipidemic nutraceutical agent on high fat diet fed streptozotocin induced type 2 diabetic rats. J Funct Foods., 14: 363-373.

Reddy, P.V., A. Urooj, S. Sairam, F. Ahmed and N.N. Prasad (2017). Hypocholesterolemic effect of Moringa oleifera polyphenols in rats fed high fat-cholesterol diet. Mal JNUT., 23(2): 473-478.

Reeves, P.G., F.H. Nielsen and G.C. Fahey (1993). AIN-93 purified diets for laboratory rodents: final report of the American Institute of Nutrition ad hoc writing

Sakr, S.A. and W.M. Al-Amoudi (2012). Effect of leave extract of Ocimum basilicum on deltamethrin induced nephrotoxicity and oxidative stress in albino rats, J. of Applied Pharmaceutical Science. 2 (5): 22-27

Schermer, S. (1967). The Blood Morphology of Laboratory Animals. $3^{\text {rd }}$ Ed., F. A. Davis Company, Philadelphia, 5-24.

Sonja, A. I. M., D.M. Jasna, C.B.G.S. Ćetković and J.J. Vulić (2009). Antioxidant activity of white grape seed extracts on DPPH radicals. APTEFF.,40: 53-61.

Souravh, B.S., G.S. Singh and R. Sharma (2014). Antiobesity and Hypolipidemic Activity of Moringa oleifera Leaves against High Fat Diet-Induced Obesity in Rats. Hindawi Publishing Corporation Advances in Biolog. ID 162914, 9 pages.

Stapleton, A.P., E.M. Goodwill, W.R. James, Brock, C. Jefferson and C.J. Frisbee (2010). Hypercholesterolemia and microvasculardysfunction: interventional strategies Journal of Inflammation 7:54

Thilakarathna, S.H. and H.P.V. Rupasinghe (2012). Antiatherosclerotic effects of fruitbioactive compounds: A review of currenscientific evidence. Canadian Journal of PlanScience, pp. 407419Usoro, C.A.O., committee on the reformulation of the AIN-76A rodent diet. Journal of Nutrition. 123:19391951.

World Health Organization (2002). The WorldHealth Report - Reducing Risks, Promoti Healthy Life. 
التأثير المثبط لاهون الدم بالمستخلصات المائية الباردة للخلطات المختلفة من أورلق الريحان وأورلق المور ينجا وبذور العنب على الفئران

علاء الدين البلتاجى ، وردة يوسف على محمد

قسم علوم وتكنولوجيا الأغذية- كلية الززاعة - جامعة المنوفية عليف علئ

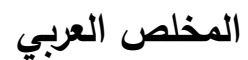

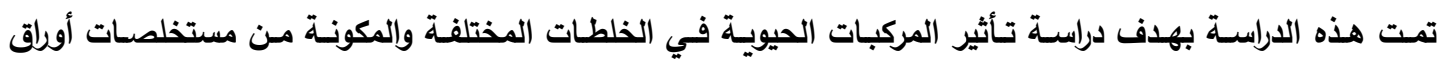

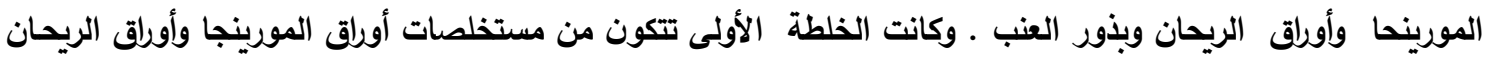

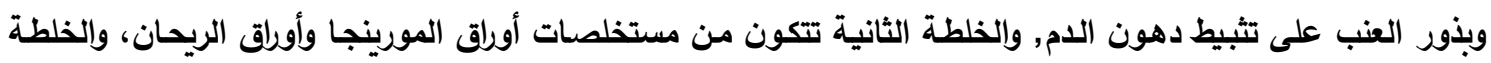

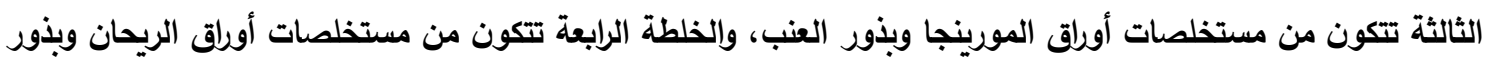

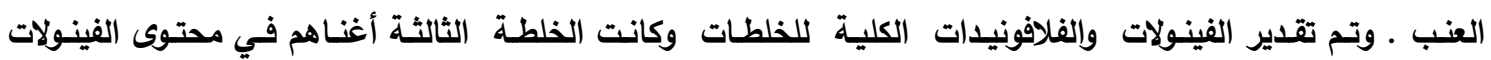

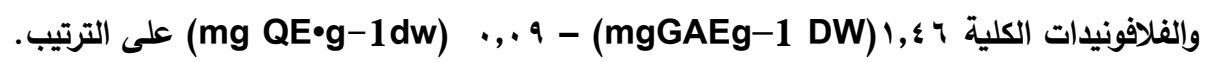

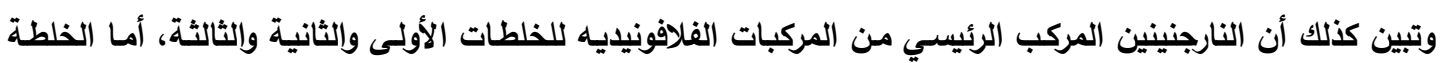
الرابعة كان الهسبردين المركب الرئيسي فيها.

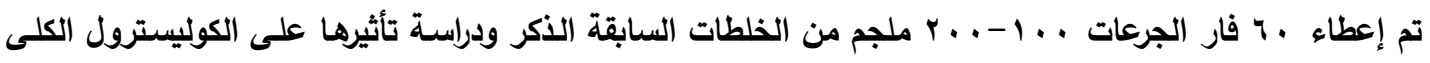

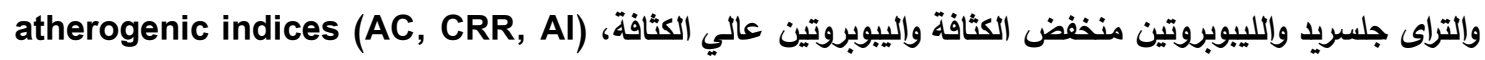

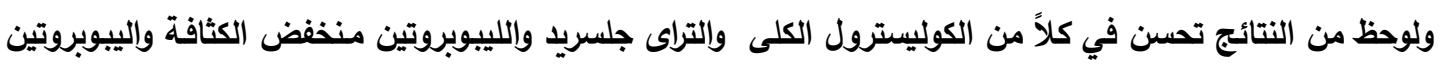

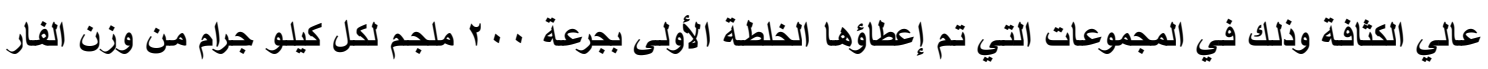

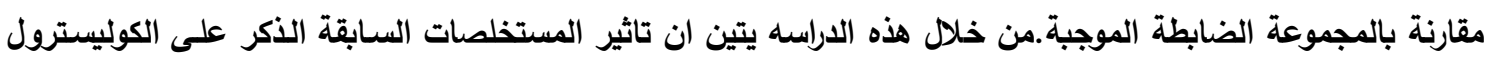

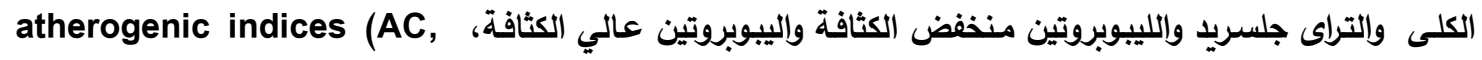

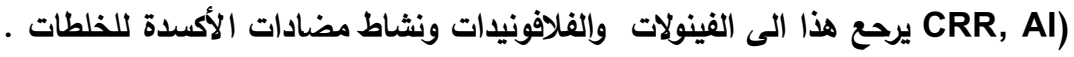

السادة المحكمين

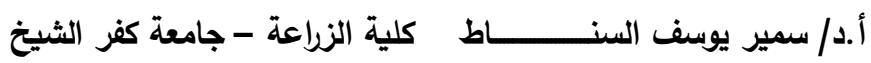

أ.د/ السيد حلمى عبدالسلام رحمه كلية الزراعة - جامعة المنوفية 
